\title{
Cerebrospinal fluid can be used for HIV genotyping when it fails in blood
}

\section{O líquido cefalorraquidiano pode ser usado para a genotipagem do HIV quando esta não é possível no plasma}

\author{
Indianara Rotta ${ }^{1,2}$, Sonia Mara Raboni ${ }^{3}$, Cléa Elisa Lopes Ribeiro ${ }^{3}$, Maristela Riedel ${ }^{4}$, Maria da \\ Graça Winhescki ${ }^{4}$, Davey M. Smith ${ }^{5}$, Ronald J. Ellis ${ }^{5}$, Sérgio Monteiro de Almeida ${ }^{1,2}$
}

\begin{abstract}
Blood plasma specimens are the clinical standard for HIV-1 pol gene genotyping from viral populations; however, it is not always successful, often from low viral loads or the presence of polymerase chain reaction (PCR) inhibitors. Objective: To describe the successful of HIV-1 genotyping in two samples of cerebrospinal fluid (CSF), after genotype procedures failed from blood. Method: Two HIV-infected patients enrolled in a neurocognitive research study were evaluated when standard HIV-1 genotyping failed from blood plasma samples. Genotyping was performed using the commercial system TRUGENE ${ }^{\circledR}$ HIV-1 Genotyping Kit and the OpenGene ${ }^{\circledR}$ DNA Sequencing System (Siemens Healthcare Diagnostics, Tarrytown, NY, USA). Results: CSF genotyping was performed via the same commercial platform and was successful in both cases. Conclusion: This report demonstrates that CSF could be used as an alternate clinical specimen for HIV-1 genotyping when it fails from blood.
\end{abstract}

Keywords: HIV-1, clades, genotyping, cerebrospinal fluid, central nervous system.

\section{RESUMO}

O plasma é a amostra clínica padrão utilizada para a genotipagem da região pol do HIV-1; entretanto, a genotipagem pode nem sempre ser bem sucedida, geralmente devido a baixas cargas virais ou à presença de inibidores da reação em cadeia da polimerase (PCR). Objetivo: Descrever o sucesso da genotipagem do HIV-1 em duas amostras de líquido cefalorraquidiano (LCR) após a falha do mesmo método em amostras de plasma dos mesmos pacientes. Método: Dois pacientes HIV+ envolvidos em um estudo neurocognitivo foram avaliados após a falha da genotipagem do HIV-1 no plasma. A genotipagem foi realizada com o sistema comercial TRUGENE ${ }^{\circledR}$ HIV-1 Genotyping e o OpenGene ${ }^{\circledR}$ DNA Sequencing (Siemens Healthcare Diagnostics, Tarrytown, NY, USA). Resultados: A genotipagem no LCR foi realizada pelo mesmo método utilizado no plasma, sendo bem sucedida para ambos os pacientes. Conclusão: Este artigo demonstra que - LCR pode ser usado como uma amostra clínica alternativa para a genotipagem do HIV-1 quando esta falha no plasma.

Palavras-chave: HIV-1, subtipos, genotipagem, líquido cefalorraquidiano, sistema nervoso central.

The international AIDS Society-USA recommends the use of genotyping for HIV-infected patients who have failing antiretroviral therapy (ART). This resistance testing should be performed while patients are still receiving their failing ART regimen ${ }^{1}$. HIV genotyping is also recommended before starting ART in patients infected by partners who have already received ART, pregnant, children and recently infected patients ${ }^{2}$.

It has been questioned the possibility of implication of certain organs by different HIV-1 subtypes, including the central nervous system $(\mathrm{CNS})^{3,4,5}$.
The clinical HIV-1 genotyping testing assay (True Gene) is designed to detect mutations, in HIV-1 protease (PR) and part of reverse transcriptase (RT) coding regions (Figure 1$)^{6}$. These regions code for the main targets of ART and where such mutations can confer resistance to these drugs. Identifying the presence of these mutations via genotyping can provide clinicians a genetic map that may guide ART to improve patient outcome ${ }^{7}$.

Blood plasma is the only biologic fluid recommended and approved for genotyping, but genotyping procedures from

\footnotetext{
${ }^{1}$ Laboratório de Virologia, Hospital de Clínicas, Universidade Federal do Paraná, Curitiba PR, Brazil;

${ }^{2}$ Instituto de Pesquisa Pelé Pequeno Príncipe, Curitiba PR, Brazil;

${ }^{3}$ Serviço de Infectologia, Hospital de Clínicas, Universidade Federal do Paraná, Curitiba PR, Brazil;

${ }^{4}$ Laboratório da Secretaria Municipal de Saúde, Curitiba PR, Brazil;

${ }^{5}$ University of California, San Diego, CA, USA.

Correspondence: Sérgio Monteiro de Almeida; Hospital de Clínicas, Universidade Federal do Paraná; Rua Padre Camargo, 280; $80060-240$ Curitiba PR, Brasil; E-mail: sergio.ma@ufpr.br

Conflict of interest: There is no conflict of interest to declare.

Support: This study was supported by NIH R21 MH76651, (PI: R. Ellis, S. Almeida).

Received 26 February 2014; Received in final form 29 April 2014; Accepted 19 May 2014.
} 


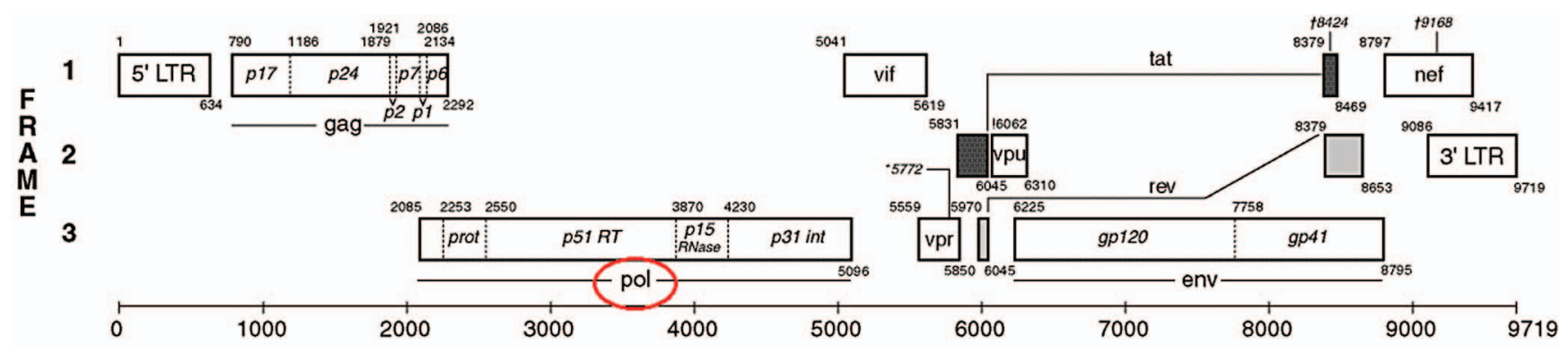

Figure 1. Schematic representation of HIV-1 genome, highlighting the pol gene region. Modified from Los Alamos ${ }^{6}$.

blood specimens are not always successful. Such assay failure is often from low viral loads ${ }^{8}$ or the presence of polymerase chain reaction (PCR) inhibitors'.

Since other tissues have been used for genotyping, like seminal plasma ${ }^{10}$, breast milk ${ }^{11}$; we investigated if cerebrospinal fluid (CSF) could be used to determine the HIV-1 subtype after genotyping failed in blood plasma.

\section{METHOD}

\section{Study population and biologic samples}

Two HIV-infected patients enrolled in a neurocognitive research study were evaluated when standard HIV-1 genotyping failed from blood plasma samples.

The Clínicas Hospital, Federal University of Paraná (HC-UFPR) Institutional Review Board and the National Ethics Committee approved this project. Written informed consent was obtained from study participants after the research procedure had been fully explained to them.

Per study procedures, blood was collected by standard venipuncture in acid-citrate-dextrose (ACD) and ethylenediamine-tetra-acetic acid (EDTA) tubes, and CSF was collected without anticoagulants by standard lumbar puncture. All specimens were stored at $-80{ }^{\circ} \mathrm{C}$ until genotyping.

\section{Viral ribonucleic acid purification}

Viral ribonucleic acid (RNA) extraction was carried out using the QIAamp ${ }^{\mathbb{R}}$ Viral RNA Mini kit (Qiagen, Valencia, CA, USA), according to manufacturer instructions from blood plasma. It was used $140 \mu \mathrm{L}$ of CSF, without centrifugation, and extracted RNA was then genotyped. HIV-1 genotyping was performed using the commercial system TRUGENE ${ }^{\circledR}$ HIV-1 Genotyping Kit and the OpenGene ${ }^{\circledR}$ desoxy-ribonucleic acid (DNA) Sequencing System (Siemens Healthcare Diagnostics, Tarrytown, NY, USA) following the manufacturer's instructions.

Specifically, the genotyping system is based on PR region of the HIV-1 pol gene from codons 10-99, and the RT region of the pol from codons 41-142 and 148-247.
To characterize genetic diversity were compared the sequences obtained to a reference panel that covered most HIV diversity from South America. Reference sequences were downloaded from Los Alamos database ${ }^{6}$. Sequences were aligned with ClustralW software and a phylogenetic tree was constructed by the bootstrapped neighbor-joining method (Mega 5.0 ${ }^{12}$, sampling trees every 2,000 generations.

When the initial genotyping from blood plasma collected in EDTA failed in our laboratory (Virology, HCUFPR, Brazil), we tried blood plasma collected in ACD. When this failed as well, we sent blood plasma collected in both ACD and EDTA for genotyping to laboratories of Secretaria Municipal de Saúde, Curitiba, Brazil (TRUGENE $^{\mathbb{R}}$ ) and University of California, San Diego, USA (Viroseq ${ }^{\circledR}$, Applied Biosystems v.2.0, Foster City, CA, USA). After all attempts to blood HIV-1 genotyping, CSF was used.

\section{RESULTS}

Per study protocols, both patients were to have HIV genotyping to classify the subtype of their infecting virus. Demographic and laboratory characteristics for both study participants are shown in the Table.

Patient 1 was not receiving ART at the time of sampling, while patient 2 was receiving ART that consisted of lamivudine (3TC), efavirenz (EFV) and tenofovir (TFV).

After genotyping failed in blood plasma, CSF collected from these individuals was used for genotyping via the same commercial platform, and genotyping from CSF was successful in both cases. Subtype analysis demonstrated that patient 1 was infected with HIV-1 circulating recombinant form $\mathrm{CF}$ and patient 2 was infected with subtype C.

Phylogenetic tree from both patients (patient 1 - B0015 and patient 2 - B0082) resulted from nucleotide sequences analysis is presented on Figure 2 . 


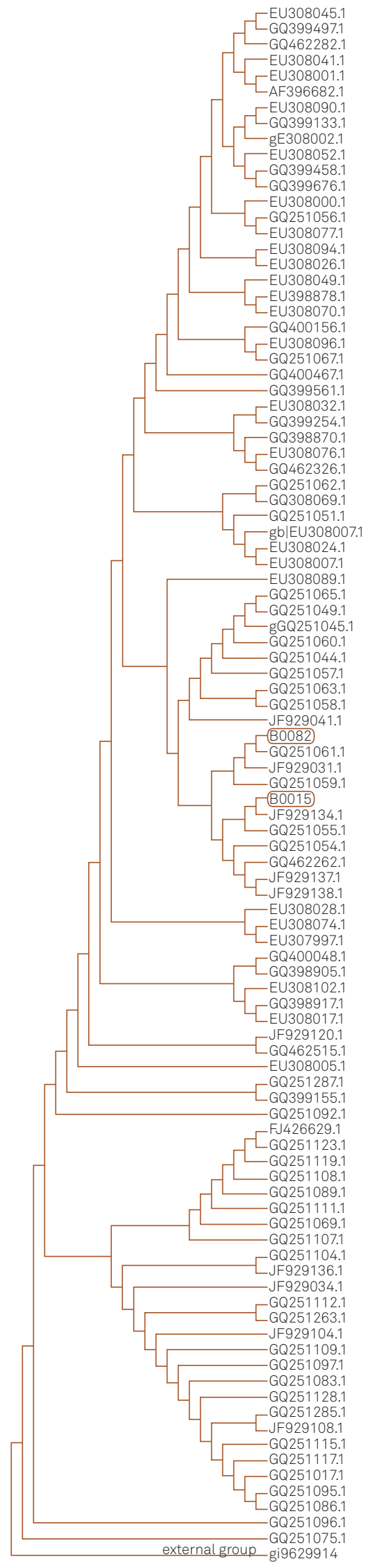

Figure 2. Phylogenetic tree resulted from nucleotide sequences analysis of HIV-1 pol gene from patient 1 (B0015) and 2 (B0082) and other HIV-1 sequences from genbank.

\section{DISCUSSION}

This study demonstrates that HIV-1 genotyping from CSF samples may be an option when genotyping from blood plasma is not possible. The unsuccessful genotyping of the viral population in blood plasma might be because of low viral loads or PCR inhibitors like hemoglobin ${ }^{13}$, immunoglobulin ${ }^{14}$; anticoagulants like EDTA ${ }^{15}$ and heparin ${ }^{16}$.

Many attempts were made in order to genotyping the HIV-1 in both two plasma samples. It was used different anticoagulants (ACD and EDTA), which are the most adequate to plasma genotyping. We have tried genotyping different regions of HIV-1 genome: besides pol, it was used specific primers to amplify the env region of the virus.

We also tried genotyping the HIV-1 env region in buffy coat samples but, as well as in plasma samples, it was not succeeded.

After a not succeeded HIV-1 plasma genotyping in our laboratory (Virology, HC-UFPR, Brazil), the samples were sent to other laboratories: Secretaria Municipal de Saúde, Curitiba, Brazil and University of California, San Diego, USA; with unsuccessful HIV-1 genotyping.

Concerning viral loads, most commercial genotyping systems recommend using blood plasma samples with at least 1,000 HIV RNA copies $/ \mathrm{mL}^{8}$. The unsuccessful of plasma but a succeeded CSF HIV-1 genotyping may be due low plasma viral load but a higher CSF viral load, in cases of controlled infection in blood but not in the CNS, as seen in patient 2 .

Plasma HIV RNA level reflects systemic viral replication but in CNS it may occur relatively independent of systemic infection and can be sufficiently inflammatory to cause the high level of pleocytosis ${ }^{17}$.

Disagreement between plasma and CSF HIV RNA viral load is defined by any detectable CSF HIV RNA viral load $>200$ copies $/ \mathrm{mL}$ while plasma viral load is $<50$ copies $/ \mathrm{mL}$ or by a CSF HIV RNA viral load $\geq 1$ log greater than the plasma $^{18}$. Patient 2 showed a CSF HIV RNA viral load 1.45 log greater than the plasma, representing a possible compartmentalization between plasma and CSF.

Another factor that may lead to a not succeeded genotyping is the presence of amplification inhibitory factors in blood, such as hemoglobin, anticoagulants like EDTA and heparin?.

Concerning PCR inhibitors, we evaluated our genotyping assay in blood plasma collected in both EDTA and ACD vials without success, even in outside laboratories.

The HIV RNA amplification of blood samples can be significantly reduced or blocked by natural components of blood, such as immunoglobulin G, due its ability to interact with single-stranded $\mathrm{DNA}^{14}$ and heme factors, which regulates DNA polymerase activity and coordinates the synthesis of hemoglobin components in erythroid cells by feedback inhibition ${ }^{13}$. 
Hemoglobin can inhibit PCR because the connection between the group heme and/or perforin with DNA polymerase inactivates the enzyme. Hemoglobin and lactoferrin were found to be major PCR inhibitors in erythrocytes and leukocytes, respectively. Both hemoglobin and lactoferrin contain iron and the inhibitory effects may be related, in part, because of their ability to release iron ions. Hemin, a hemoglobin derivative, and its metabolites, bilirubin and bile salts, are also PCR inhibitors?.

The inhibitory effect of heparin has been suggested on the basis of an interaction between heparin and DNA, which could be mediated by $\mathrm{Mg}^{2+}{ }^{16}$. The inhibition by EDTA, the anticoagulant used in our samples, may be related to its ability to inhibit DNA synthesis by chelating the $\mathrm{Mg}^{2+}$ necessary to DNA polymerase activity ${ }^{15}$.

Finally, we theorize that genotyping in blood failed in patient 2 because of HIV viral loads were lower in blood than CSF, while genotyping in blood failed in patient 1 because of a PCR inhibitor present in the blood plasma.

In conclusion, we demonstrated that it is possible to carry out HIV-1 genotyping in CSF samples by using the
Table. Participant characteristics.

\begin{tabular}{lcc} 
& Patient 1 & Patient 2 \\
\hline Gender & Male & Male \\
Age & 48 & 27 \\
HIV-1 clade & CF & C \\
CDC classification & A2 & C3 \\
Current CD4+cell/mm $\mathrm{mm}^{3}$ & 318 & 239 \\
Nadir CD4+cell/mm & 300 & 6 \\
Blood HIV RNA copies/mL & 6,230 & 841 \\
CSF HIV RNA copies $/ \mathrm{mL}$ & 633 & 23,821 \\
CSF White Blood Cell cell/ $\mu$ L & 12 & 20 \\
CSF Total Protein $\mathrm{mg} / \mathrm{dL}$ & 33 & 339 \\
\hline
\end{tabular}

TRUGENE $^{\circledR}$ HIV-1 Genotyping Kit, when genotyping was not possible from blood plasma samples.

\section{Acknowledgments}

We would like to thank Secretaria Municipal de Saúde de Curitiba and University of California, San Diego.

\section{References}

1. Hirsch MS, Brun-Vézinet F, D’Aquila RT, et al. Antiretroviral drug resistance testing in adult HIV-1 infection: recommendations of an International AIDS Society-USA Panel. JAMA 2000;283:2417-2426.

2. Ministério da Saúde (MS), Brasil. Secretaria de Vigilância em Saúde. Departamento DST, AIDS e Hepatites Virais. Protocolo Clínico e Diretrizes terapêuticas para adultos vivendo com HIV/AIDS. Available at http://www.aids.gov.br/pcdt/protocolo-clinico. Accessed: 10/09/2013.

3. Sacktor N, Nakasujja N, Skolasky RL, Rezapour M, Robertson K, Musisi S. HIV subtype D is associated with dementia, compared with subtype $A$, in immunosuppressed individuals at risk of cognitive impairment in Kampala, Uganda. Clin Infect Dis 2009;49:780-786.

4. Sacktor N, Nakasujja N, Redd AD, et al. HIV subtype is not associated with dementia among individuals with moderate and advanced immunosuppression in Kampala, Uganda. Metab Brain Dis 2014. Epub ahead of print 12 Feb 2014. DOI: 10.1007/s11011-014-9498-3.

5. Almeida SM, Smith D, Raboni SM, Rotta I, Heaton RK, Ellis RJ. Neurocognitive impairment in HIV-1 clade C- versus B-infected individuals in Southern Brazil. J Neurovirol. 2013;19:550-556.

6. Los Alamos. HIV database. Available at http://www.hiv.lanl.gov. Accessed: 09/20/2013.

7. Ministério da Saúde (MS), Brasil. Programa Nacional de DST/AIDS Available at http://www.aids.gov.br/sites/default/files/anexos/publicacao/2012/52654/boletim_2012_final_1_pdf_21822.pdf. Accessed: $02 / 10 / 2014$

8. Grant RM, Kuritzkes DR, Johnson VA, et al. Accuracy of the TRUGENE HIV-1 Genotyping Kit. J Clin Microbiol 2003;41:1586-1593.

9. Al-Soud WA, Rådström P. Purification and characterization of PCR inhibitory components in blood cells. J Clin Microbiol 2001;39:485-493.
10. Eron JJ, Vernazza PL, Johnston DM, et al. Resistance of HIV-1 to antiretroviral agents in blood and seminal plasma: implications for transmission. AIDS 1998;12:181-189.

11. Becquart P, Chomont N, Roques P, et al. Compartmentalization of HIV-1 between breast milk and blood of HIV-infected mothers. Virology 2002;300:109-117.

12. Tamura K, Stecher G, Peterson D, Kumar S. Molecular evolutionary genetics analysis. Available at http://www.megasoftware.net// Accessed: 09/20/2013.

13. Akane A, Matsubara K, Nakamura H, Takahashi S, Kimura K Identification of the heme compound copurified with deoxyribonucleic acid (DNA) from bloodstains, a major inhibitor of polymerase chain reaction (PCR) amplification. J Forensic Sci 1994;39:362-372.

14. Al-Soud WA, Jönsson LJ, Râdström P. Identification and characterization of immunoglobulin $G$ in blood as a major inhibitor of diagnostic PCR. J Clin Microbiol 2000;38:345-350.

15. Rossen L, Nørskov P, Holmstrøm K, Rasmussen OF. Inhibition of PCR by components of food samples, microbial diagnostic assays and DNA-extraction solution. Int J Food Microbiol 1992;17:37-45.

16. Satsangi J, Jewell DP, Welsh K, Bunce M, Bell Jl. Effect of heparin on polymerase chain reaction. Lancet 1994;343:1509-1510.

17. Smith, DM, Zárate, Ellis RJ, et al. Pleocytosis is associated with disruption of HIV compartmentalization between blood and cerebral spinal fluid viral populations. Virology 2009;385:204-208.

18. Canestri A, Lescure FX, Jaureguiberry S, et al. Discordance between cerebral spinal fluid and plasma HIV replication in patients with neurological symptoms who are receiving suppressive antiretroviral therapy. Clin Infect Dis 2010;50:773-778. 